\title{
Protein Precipitation
}

National Cancer Institute

\section{Source}

National Cancer Institute. Protein Precipitation. NCI Thesaurus. Code C113065.

The process of precipitating proteins from solution. Protein precipitation may be bulk and general or specific. 